УДК 664.8.037.1: 634.11

DOI https://doi.org/10.32838/2663-5941/2019.6-2/22

\title{
Мельник О.В.
}

Уманський національний університет садівництва

\section{Худік Л.М.}

Уманський національний університет садівництва

\section{ДЕГУСТАЦІЙНА ОЦІНКА ЯБЛУК 3 ОБРОБКОЮ 1-МЕТИЛЦИКЛОПРОПЕНОМ}

Смакові та структурні характеристики свіжих плодів визначають попит і формують стійку привабливість продукиії для споживача. Споживча якість яблук визначається ароматом, соковитістю плоду, вдалим кисло-солодким смаком і достатньою твердістю м'якоті, що вказує на свіжість $i$ корисність продукиії, проте активно втрачається під час тривалого холодильного зберігання. Покращичти смакові властивості свіжої продукції можливо за післязбиральної обробки плодів 1-метилциклопропеном (1-МЦП), механізм дії якого спрямований на блокування біологічної дї̈ гормону старіння плодів етилену та суттєвого уповільнення їхнього фізіологічного дозрівання і покращення якості на кінеиь зберігання.

У статті досліджено вплив післязбиральної обробки 1-МЦП яблук сорту Кальвіль сніговий $і$ Спартан ранньозимового строку достигання на основні показники спожсивчої якості плодів після шестимісячного зберігання в умовах холодильника зі звичайною атмосферою. Зафіксовано кращі оцінки смакових якостей оброблених 1-МЦП плодів, порівняно з контролем. Показано переважаючий вплив післязбиральної обробки 1-МЦП на формування у респондентів високої відзнаки твердості, хрусткості та соковитості яблук, а також відзначення їхньої високої якості за показником загальної дегустаційної оиінки. Доведено, що обробка 1-МЦП не впливає на формування солодкого смаку яблук сорту Кальвіль сніговий та аромату плодів, проте респондентами зазначено вищі, порівняно з контролем, оцінки останнього для сорту Спартан. Отримані закономірності підтверджують наявні дані літературних джерел із цьвого питання.

Ключові слова: споживча якість, 1-МЦП, післязбиральна обробка, яблука, продукиія, соковитість, аромат, солодкість, твердість, дегустаиіийна оичнка.

Постановка проблеми. У процесі дозрівання яблук під час тривалого зберігання знижується їхня загальна біологічна цінність і смакові властивості внаслідок необоротних змін у кількісно-якісному складі й співвідношенні основних показників харчової цінності плодів, а також розм'якшення тканин та розпаду структури м'якоті, що призводить до суттєвої втрати товарних якостей продукції та формує незадовільний смаковий ефект для споживача.

Збереження якості продукції й уповільнення дозрівання досягається післязбиральною обробкою яблук інгібітором етилену 1-метилциклопропеном (1-МЦП), що забезпечує ефективне збереження смакових якостей плодів після зберігання, зумовлюючи зниження втрат соковитості, твердості, свіжості плодів і формує їхній приємний кисло-солодкий смак.

Аналіз останніх досліджень i публікацій. Споживча якість яблук визначається структурою, смаком та ароматом плоду [1]. Струк- тура базується на механічних характеристиках м'якоті (хрусткість, твердість, борошнистість) та соковитості. Смак визначається солодкістю, кислістю та терпкістю. Аромат асоціюється із запахом і визначається наявністю летких ароматичних сполук [2].

Споживачі віддають перевагу різним поєднанням структурних, смакових та ароматичних характеристик. Дослідники 3 Великобританії [3] встановили, що більшість споживачів віддає перевагу хрустким і соковитим плодам із помірною кислотністю і цукристістю (сорти Емпайр, Бреберн, Джонаголд, Квін Конс, Фієста), менше - доволі твердим сортам із високою кислотністю плоду (Грані Сміт), сорти із зниженою кислотністю й підвищеним вмістом цукрів (Голден Делішес, Ред Делішес, Гала) - менш популярні. Суттєво впливають на органолептичні якості свіжих плодів ступінь стиглості, способи післязбиральної обробки, режими зберігання та сортові особливості плодів [4]. 
Напрацювання вчених різних країн свідчать про високу ефективність сполуки 1-метилциклопропену у збереженості структурно-механічних і смакових властивостей яблук під час тривалого зберігання [5-7], що пояснюється його здатністю блокувати у плодах рецептори чутливості до етилену - головного ініціатора їхнього фізіологічного достигання [8; 9]. У результаті уповільнюються процеси обміну [10-12], що сприяє збереженості щільності м'якоті, біологічно-активних речовин i, як наслідок, - смакових і структурних характеристик, а також подовженню строку реалізації продукції до весни-літа наступного року з максимально можливими показниками споживчої якості навіть за зберігання в умовах атмосфери повітря i підвищених температурних режимів холодильних камер [13; 14].

Дослідники з Латвії встановили [15], що після шести місяців зберігання у регульованій атмосфері плоди осіннього сорту Ауксис володіли вираженою соковитістю та гарним забарвленням, тоді як оброблені 1-МЦП яблука зі звичайної атмосфери визнано солодшими та ароматнішими. Ще раніше іншими латвійськими вченими [16] не доведено суттєво позитивного впливу обробки 1-МЦП на загальну смакову якість традиційних сортів яблук упродовж дев'яти місяців зберігання, хоча після шести місяців у холодильнику плоди з 1-МЦП більш соковиті і твердіші, порівняно 3 контролем. Дослідженнями ізраїльських учених показано, що 1-МЦП не впливає на смак яблук [17], а вчені з Хорватії зазначили високу ефективність післязбиральної обробки 1-МЦП на смакові якості плодів сорту Грані Сміт після холодильного зберігання в умовах атмосфери [18].

Обробка 1-МЦП дещо стримує розкриття аромату плодів під час зберігання $[19 ; 20]$, що $є$ результатом впливу речовини на біосинтез летких ароматичних сполук [21].

Отже, післязбиральна обробка 1-МЦП стримує утворення аромату яблук, проте ефективно покращує органолептичну та споживчу якість плодів, забезпечуючи на кінець зберігання задовільну соковитість, твердість, свіжість і вдалий солодкокислий смак продукції. 3 огляду на наявні результати доцільним є дослідження впливу інгібітора дії етилену на дегустаційні показники вирощених в Україні яблук ранньозимового строку достигання.

Постановка завдання. Мета статті - на основі вивчених наявних експериментальних даних дослідити вплив післязбиральної обробки 1-метилциклопропеном (препарат «SmartFresh») на смакові властивості яблук ранньозимових сортів Кальвіль сніговий і Спартан після шестимісячного зберігання у фруктосховищі-холодильнику.

Виклад основного матеріалу дослідження. Плоди 3 попереднім охолодженням до $+5 \pm 2^{\circ} \mathrm{C}$ i без нього після збирання обробляли 1-метилци-

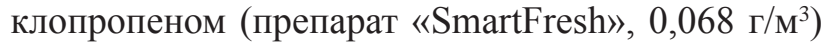
(без обробки - контроль) та зберігали у фруктосховищі-холодильнику $\Phi \mathrm{X}-770$ Уманського національного університету садівництва за температури $3 \pm 1^{\circ} \mathrm{C}$ та відносної вологості повітря 85-90\%. Температуру в камері контролювали спиртовими термометрами, відносну вологість повітря - гігрометром.

У день збору половину продукції охолоджували за температури $5 \pm 2^{\circ} \mathrm{C}$ і відносної вологості повітря 85-90\% та обробляли 1-метилциклопропеном за рекомендацією виробника препарату SmartFresh (без обробки - контроль). Ящики 3 плодами ставили в газонепроникний контейнер 3 плівки завтовшки 200 мк, куди вміщували склянку 3 дистильованою водою і розрахованою на одиницю об'єму дозою порошкоподібного препарату «SmartFresh» $\left(0,068\right.$ г/м $\left.{ }^{3}\right)$. Циркуляцію повітря в контейнері здійснювали вентилятором. Іншу частину продукції обробляли одразу після збирання.

Відбір проб і підготовку плодів до зберігання здійснювали за ГСТУ 01.1-37-160:2004. Органолептичну оцінку якості плодів визначали за десятибальною шкалою за основними показниками споживчої якості плодів - ароматом, твердістю, соковитістю, хрусткістю, солодкістю, кислим смаком і загальною оцінкою - постійно діючою дегустаційною комісією в кількості 10 осіб. Перед аналізуванням закодованих зразків плоди витримували впродовж 12-18 год за температури $18 \pm 2^{\circ} \mathrm{C}$.

Статистичну обробку даних проводили методами дисперсійного та кореляційного аналізів із використанням комп'ютерних програм «MS Office Excel 2010» і «Statistica-10-En» й аналізували за рекомендаціями В.Ф. Мойсейченка [22].

Встановлено, що післязбиральна обробка плодів 1-МЦП забезпечила значно вищі значення показників органолептичної оцінки яблук ранньозимового строку достигання, порівняно з необробленою продукцією (рис. 1).

Для оброблених «СмартФреш» яблук сорту Кальвіль сніговий із попереднім охолодженням оцінка аромату не різнилася з такими без обробки, для яблук без попереднього охолодження - нижча на 0,6 бала. Для сорту Спартан різниця становила відповідно 0,9 та 0,8 бала на користь оброблених 
яблук. Твердість охолоджених без обробки яблук обох помологічних сортів відзначена на 0,5 бала нижчою, порівняно з неохолодженими, а оброблених 1-МЦП - відповідно на 0,4 та 0,6 пункти вища 3 максимальним показником 6,3 балів для охолоджених сорту Кальвіль сніговий, що в середньому на 1,0-1,2 бали більше, порівняно із сортом Спартан. Післязбиральна обробка 1-МЦП забезпечила вищу на 1,4-2,3 бала оцінку показника яблук сорту Кальвіль сніговий і на 1,3-2,4 бала - сорту Спартан, порівняно з необробленими плодами.

Аналогічно до твердості відзначено й хрусткість м'якоті плоду, коли різниця оцінки показника для варіантів контролю без попереднього охолодження на 0,2-0,3 бала вища, порівняно 3 охолодженими сорту Кальвіль сніговий і Спартан. Для оброблених 1-МЦП суттєво вища на 0,5-0,6 бала оцінка показника в попередньо охолоджених сортів Кальвіль сніговий і Спартан, порівняно 3 плодами без охолодження. Максимальною оцінкою 6,1 балів на кінець зберігання відзначено хрусткість оброблених 1-МЦП яблук сорту Кальвіль сніговий із попереднім охолодженням, що на 0,8-1,4 пункти вище, ніж оцінка сорту Спартан. Загалом, за обробки 1-МЦП хрусткість плодів сорту Кальвіль сніговий оцінено вище на 1,6-2,3, а сорту Спартан - на 1,5-2,4 бала, порівняно 3 необробленими.

Оцінка соковитості охолоджених яблук контролю також нижча, порівняно з неохолодженими на 0,2 бала для сорту Кальвіль сніговий і на 0,5 бала - сорту Спартан. Для попередньо охолоджених з обробкою 1-МЦП вона на 0,6 бала вища, порівняно з неохолодженими, тоді як для плодів сорту Спартан - несуттєво нижча. Вище на 0,2-0,9 бала відзначено дегустаторами соковитість яблук сорту Кальвіль сніговий $(5,3-$ 5,9 балів), порівняно з іншим помологічним сортом, а перевага рівня показника за обробки 1-МЦП склала 1,3-2,1 та 1,5-1,9 балів відповідно для плодів сорту Кальвіль сніговий і Спартан.

На кінець зберігання солодкість яблук усіх варіантів визнано помірно середньою 3 максимальним рівнем 5,5 балів для оброблених плодів сорту Спартан без попереднього охолодження, що на 0,5-0,9 бала вище, порівняно 3 оцінкою оброблених плодів сорту Кальвіль сніговий. Оцінка солодкості охолоджених плодів контролю сорту Спартан на 0,5 бала нижча, ніж без охолодження, тоді як відзнака показника для таких же 3 обробкою 1-МЦП сорту Кальвіль сніговий на 0,4 пункти вища. В середньому післязбиральна

\section{Кальвіль сніговий}

$$
\text { apoмaт }\left(H I P_{05}=0,3\right)
$$

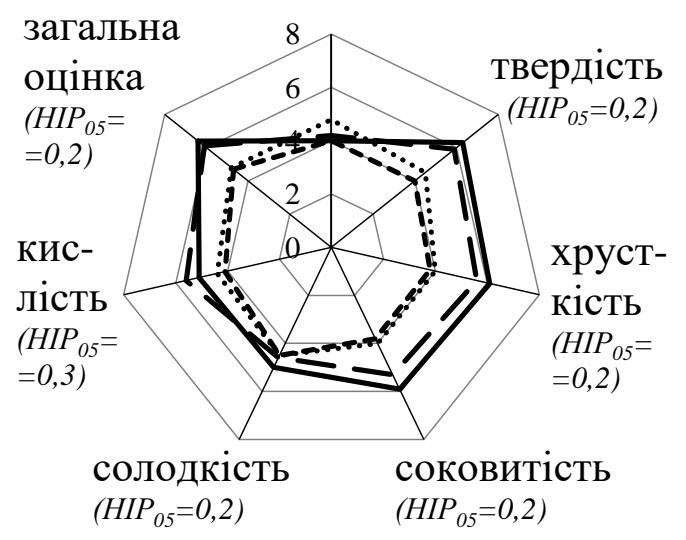

без попереднього

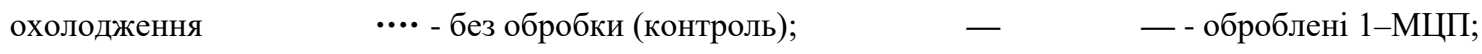

$$
\begin{aligned}
& 3 \text { попереднім } \\
& \text { охолодженням - ---- - без обробки (контроль); }
\end{aligned}
$$

\section{Cnapmar}

$\operatorname{apomat}\left(H I P_{05}=0,3\right)$

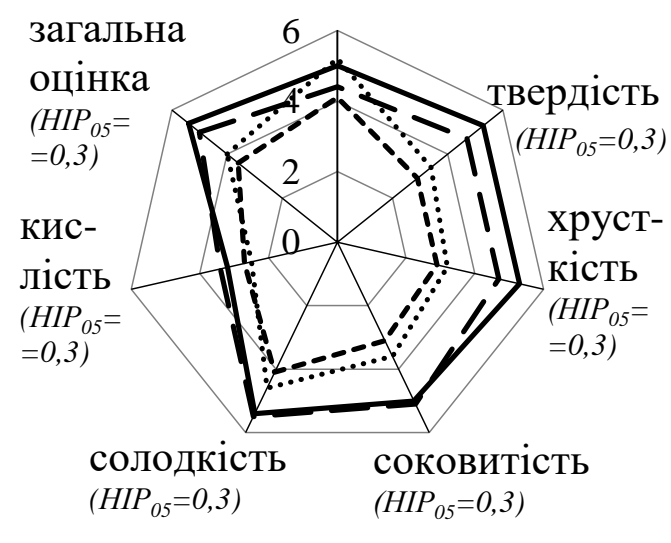

Рис. 1. Органолептична оцінка яблук з післязбиральною обробкою 1-МЦП після шестимісячного зберігання (середнс із врожаю 2012-2013 рр.) 
обробка 1-МЦП зумовила вищу на 0,9-1,5 бала оцінку солодкості яблук сорту Спартан і на 0,5 бала - охолоджених сорту Кальвіль сніговий, порівняно з відзначенням показника для необроблених плодів.

Кислий смак охолоджених яблук сорту Кальвіль сніговий відзначено нижчим, ніж неохолоджених, а необроблених сорту Спартан - несуттєво вищим. Порівняно з плодами сорту Спартан, необроблені яблука сорту Кальвіль сніговий визнано кислішими на 1,4-1,9 бала, оброблені 1-МЦП - на 1,9-2,2 бала кисліші. Оцінка кислого смаку плодів цього сорту за обробки 1-МЦП вища на 1,01,2 бали, сорту Спартан - на 0,5-0,9 бала, порівняно $з$ позицією необроблених. Подібні результати одержано О. Дрозд для яблук зимових сортів Джонаголд, Голден Делішес і Грані Сміт [23].

Порівняно з плодами без обробки, де вищим показником загальної оцінки відзначено плоди без охолодження, рівень показника оброблених 1-МЦП на 0,3-0,4 бала суттєво вищий для яблук iз попереднім охолодженням сорту Кальвіль сніговий і Спартан, а післязбиральна обробка «СмартФреш» зумовила відповідно на $1,3-1,7$ та $1,0-$ 1,8 бали вищу оцінку загального смаку цих плодів. Загалом, після шестимісячного зберігання попередньо охолоджені плоди сорту Кальвіль сніговий із післязбиральною обробкою 1-МЦП вирізнялись максимальною серед усіх варіантів вище середньої загальною оцінкою 6,4 бали, а $85 \%$ дегустаторів відзначили ці плоди як кращий зразок.

За результатом дисперсійного аналізу, показники споживчої якості яблук залежали переважно від оцінки респондентів та післязбиральної обробки 1-МЦП (дані не наведено). Аромат яблук сорту Кальвіль сніговий і Спартан відповідно на 94 та 96\% визначався вподобаннями дегустаторів, а впливу післязбиральної обробки 1-МЦП не зафіксовано.
Твердість, соковитість і хрусткість яблук на понад $60 \%$ визначалась оцінками респондентів, а обробка 1-МЦП найбільше (30\%) впливала на відзнаку хрусткості плодів сорту Кальвіль сніговий та загальну дегустаційну оцінку яблук обох сортів (25 і 13\% відповідно). Кислий смак яблук сорту Кальвіль сніговий на 13\% визначався післязбиральною обробкою 1-МЦП, а на солодкість плодів обох досліджуваних сортів впливу обробки 1-МЦП не виявлено.

Висновки. Післязбиральна обробка яблук 1-МЦП забезпечує суттєво кращі показники органолептичної оцінки плодів після шести місяців зберігання, порівняно з необробленими, а яблука 3 попереднім охолодженням обох помологічних сортів визнано кращими за всіма показниками споживчої якості. Після шести місяців холодильного зберігання оцінка респондентами твердості, хрусткості і соковитості оброблених 1-МЦП яблук сорту Кальвіль сніговий і Спартан вища, порівняно з плодами без обробки, в середньому на 1,5-2,5 балів. Для оброблених 1-МЦП яблук сорту Спартан після зберігання більш виражений солодкий смак, а для сорту Кальвіль сніговий - кислий. Аромат оброблених 1-МЦП яблук сорту Спартан визнано на 0,8-0,9 бала кращим, ніж необроблених, а плодів сорту Кальвіль сніговий без охолодження - на 0,6 бала гіршим. Найвищою 3-поміж варіантів оцінкою загального смаку продукції 6,4 балів відзначено оброблені яблука сорту Кальвіль сніговий із попереднім охолодженням. Післязбиральна обробка 1-МЦП найбільше впливає на рівень твердості, хрусткості та соковитості та на показник загальної дегустаційної оцінки яблук обох помологічних сортів.

Перспективами подальших досліджень $€$ визначення динаміки споживчих якостей продукції під час зберігання у взаємозв'язку з аналітичними результатами фізико-хімічного стану плодів.

\section{Список літератури:}

1. Peneau S., Hoehn E., Roth H.R., Escher F., Nuessli J. Importance and consumer perception of freshness of apples. Food Chemistry. 2006. Vol. 17. P. 9-19.

2. Criner G.K., Kezis A.S., Cheng H., Nord M. Apple preferences, formulation and testing: Red Delicious, McIntosh and Empire. Journal of Food Distribution Research. 1995. Vol. 26. P. 64-71.

3. Patterson P.M., Richards T.J. Newspaper advertisement characteristics and consumer preferences for apples: a MIMIC model approach. Agribusiness. 2000. Vol. 16. P. 159-177.

4. Rutkowski K.P., Markowski J., Siucińska K. The influence of harvest date, SmartFreshSM (1-MCP) treatment and storage conditions on quality of 'Shampion' apples. $3^{\text {rd }}$ International Conference "Effects of Pre- and Postharvest Factors on Health Promoting Components and Quality of Horticultural Commodities», March 23-25, 2014. Skierniewice, Poland, 2014. P. 25.

5. Marin A.B. Colonna A.E., Kudo K., Kupferman E.M., Mattheis J.P. Measuring consumer response to Gala apples treated with 1-methylcyclopropene (1-MCP). Postharvest biology and technology. 2009. Vol. 51. P. 73-79.

6. Kolniak-Ostek J., Wojdylo A., Markovski J., Siuchinska K. 1-methylcyclopropene postharvest treatment and their effect on apple quality during long-term storage time. Europe food response technology. 2014. Vol. 239. P. 603-612. 
7. Zanella A., Stuerz S., Cazzanelli P., Cecchinel M., Rossi O. Benefits in apple fruit firmness retention after harvest achieved due to SmartFresh (1-MCP) treatment or dynamic controlled atmosphere storage by means of chlorophyll fluorescence (DCA-CF). $3^{\text {rd }}$ International Conference "Effects of Pre- and Post-harvest Factors on Health Promoting Components and Quality of Horticultural Commodities". March 23-25, 2014. Skierniewice, Poland, 2014. P. 24.

8. Blankenship S.M., Dole J.M. 1-Methylcyclopropene: A review. Postharvest Biology and Technology. 2003. Vol. 28. P. 1-25.

9. Beaudry R., Watkins C. Use of 1-MCP on apples. N.Y. Fruit Quarterly. 2003. Vol. 11. P. 11-13.

10. Fan X., Blankenship S.M., Mattheis J.P. 1-methylcyclopropene inhibits apple ripening. Journal of American Soc. Horticultural Science. 1999. Vol. 124. P. 690-695.

11. DeLong J.M., Prange R.K., Harrison P.A. The influence of 1-methylcyclopropene on 'Cortland' and 'McIntosh' apple quality following long-term storage. HortScience. 2004. Vol. 39. P. 1062-1065.

12. Watkins C., Nock J., James H. Rapid application of SmartFreshTM (1 MCP) to apples after harvest is more important than rapid CA. N.Y. Fruit Quarterly. 2010. Vol. 16. P. 3-9.

13. Гудковський В.А. Новая технология хранения и транспортировки плодов и овощей с использованием препарата «Фитомаг». Овощеводство и тепличное хозяйство. 2007. №10. С. 51-53.

14. Гудковский В.А., Кладь А.А., Кожина Л.В., Балакирев А.Е., Назаров Ю.Б. Прогрессивные технологии хранения плодов. Достижения науки и техники АПК. 2009. № 2. С. 66-68.

15. Juhnevica-Radenkova K., Radenkov V. Influence of 1-methylcyclopropene and ULO conditions on sensory characteristics of apple fruit grown in Latvia. Journal of Horticultural Research. 2016. Vol. 24. № 1. P. 37-46.

16. Juhnevica K., Skudra L., Skrivete M., Radenkovs V., Seglina D., Stepanovs A. Effect of 1-methylcyclopropene treatment on sensory characteristics of apple fruit. Environmental and Experimental biology. 2013. Vol. 11. P. 99-105.

17. Pre-Aymard C., Fallik E., Weksler A., Lurie S. Sensory analysis and instrumental measurements of 'Anna' apples treated with 1-methylcyclopropene. Postharvest Biology and Technology. 2005. Vol. 36. P. 135-142.

18. Jemric T., Fruk G., Kortylewsca D., Aljinovic S. Postharvest quality and sensory characteristics of Granny Smith apple treated with SmartFresh ${ }^{\mathrm{TM}}$ (1-MCP). Agriculture conspectus Sientificus. 2012. Vol. 77. № 4. P. 211-215.

19. Lurie S., Pre-Aymard C., Ravid U., Larkov O., Fallik E. Effect of 1-methylcyclopropene on volatile emission and aroma in cv. Anna apples. Food Chemistry. 2002. Vol. 50. P. 4251-4256.

20. Rupasinghe H.P., Murr D.P., Paliyath G., Skog L. Inhibitory effect of 1-MCP on ripening and superficial scald development in "McIntosh" and "Delicious" apple. HortScience. 2000. Vol. 75. P. 271-276.

21. Vidrin R., Hribar J., Zlatic E. The aroma profile of apples as influence by 1-MCP. Journal of Fruit and Ornamental Plant Research. 2011. Vol. 19. № 1. P. 101-111.

22. Мойсейченко В.Ф. Основи наукових досліджень у плодівництві, овочівництві, виноградарстві та технології зберігання плодоовочевої продукції. Київ : НМК ВО, 1992. 364 с.

23. Мельник О.В., Дрозд О.О. Органолептична оцінка яблук 3 післязбиральною обробкою інгібітором етилену. Збірник наукових пращь Уманського національного університету садівництва. 2012. Ч. 1. Вип. 81. C. 233-238.

\section{Melnyk O.V., Khudik L.M. TASTING EVALUATION OF APPLES WITH 1-METHYLCYCLOPROPENE TREATMENT}

Consumer quality of the apples is determined by the aroma, juiciness of the fruit, good sour-sweet taste and sufficient firmness of the flesh, which indicates the freshness and usefulness of the produce, but is actively lost during long-term refrigerated storage. Improving the taste properties of fresh produce is possible by the postharvest treatment of fruits with 1-methylcyclopropene (1-MCP), whose action mechanism is aimed to blocking the biological action of ethylene - the hormone of fruits aging and significantly slow down their physiological maturation and improve quality at the end of storage.

The effect of post-harvest treatment with 1-MCP of early winter apple varieties Calvil and Spartan on the basic indicators of fruit consumer quality after six months storage under atmosphere refrigerated conditions is investigated. Compared to the control, the best estimates of the treated 1-MCP fruits taste qualities were recorded. The prevailing influence of post-harvest treatment with 1-MCP on the formation into respondents high marks of hardness, crunchiness and juiciness of apples and also their high quality by the overall tasting evaluation, is shown. It has been proved that the 1-MCP treatment doesn't influence on the formation sweet taste Calvil apples and the aroma of fruits both varieties, but the respondents noted higher, compared with the control, aroma for the Spartan fruits.

In general, the 1-MCP treated apples of both varieties had better firmness, juiciness, crunchiness and higher acidity compared to the untreated fruits. After six months storage the pre-cooled 1-MCP treated Calville fruits had the highest overall quality rating, and most tasters rated these fruits as the best sample. Obtained regularities are confirmed by the existing literary data of this subject.

Key words: consumer quality, 1-MCP, post-harvest treatment, apples, produce, juiciness, aroma, sweetness, hardness, tasting evaluation. 